\title{
The Incidence of Mucositis in Children with Chemotherapy Treatment
}

\author{
Sri Hendrawati, Ikeu Nurhidayah, Henny Suzana Mediani, Ai Mardhiyah \\ Faculty of Nursing, Universitas Padjadjaran \\ Email: sri.hendrawati@unpad.ac.id
}

\begin{abstract}
Currently, cancer is the top ten cause of child mortality in Indonesia. Chemotherapy is an effective intervention to treat cancer children, however, has side effects, including mucositis. The prevalence of mucositis in cancer children is estimated to reach $45-80 \%$, which has implications for the children's' quality of life. The purpose of this study was to identify the occurrence of mucositis in cancer children who received chemotherapy treatment. The study was conducted at Dr. RSUP Hasan Sadikin Bandung. This research method was descriptive quantitative. The consecutive sampling technique was used to determine the respondent as the study sample so that 60 respondents were obtained. The process of collecting data used the Oral Assessment Guide (OAG) study instrument in the form of a checklist sheet. Data were analyzed using frequency distribution and percentage. The results showed that almost all cancer children with chemotherapy treatment experienced mucositis which is 53 people (88.3\%) and a small proportion of 7 people $(11.7 \%)$ did not experience mucositis. Almost all cancer children who get chemotherapy treatment experience mucositis. Nurses as health workers who are most often with patients should be able to improve nursing care for cancer children who receive chemotherapy treatment in minimizing the occurrence of mucositis by conducting routine mucositis assessment and oral care to improve the quality of life in cancer children.
\end{abstract}

Keywords: Cancer, chemotherapy, children, mucositis. 
Sri Hendrawati: The Incidence of Mucositis in Children with Chemotherapy Treatment

\section{Introduction}

Cancer is a chronic disease that is frightening for everyone because the cancer death rate is very high. According to the World Health Organization (WHO) report in 2009, every year more than 10 million cases of cancer identified and is predicted to increase by $20 \%$ annually. It is estimated that by 2020 the number of new cancer cases will increase to almost 20 million people. Currently, cancer is the top ten cause of child mortality in Indonesia (RI Ministry of Health, 2017).

Cancer incidence is high especially in developing countries (MOH, 2009). There are more than $85 \%$ of cases of childhood cancer occurring in developing countries, including in Indonesia, and it is estimated that in the coming decade it would increase to $90 \%$ (Mandiacloqlu \& Pamukcu, 2004). According to data from the Indonesian Children's Oncology Foundation, it showed that $2-3 \%$ of the number of cancers in Indonesia occur in children, which is around 150 out of 1 million children. It is estimated that every year there are 4,100 new cases of cancer in children in Indonesia (Umiati, 2010).

Cancer in children is different from cancer in adults. Hockenberry and Wilson (2009) stated that there are four types of cancer that are often experienced by children, including leukemia, lymphoma, central nervous system tumors, and solid tumors. Leukemia is a type of cancer that is often found in children. The treatment of leukemia is most often only done with chemotherapy without radiotherapy and surgery. This can also increase the number of children who get chemotherapy plus other cancer cases that also get treated with chemotherapy.

Chemotherapy is the most common therapy for the treatment of children with cancer because it works effectively especially for systemic cancers that cannot be treated with surgery or radiation. Multiagent chemotherapy provides many successes in children with cancer and saves many children (Bartucci, Rosanna, \& Daniela, 2011). On the other hand, chemotherapy also has a disadvantage. This therapy is not only destroyed malignant cells but also killing other cells that are growing rapidly, such as intestinal mucous cells, blood cells, or hair follicles. This results in various side effects of chemotherapy that occur in various systems, including the hematopoietic, digestive, hepatic, kidney, skin and reproductive systems.

The side effects of this therapy depend on the type and dose of chemotherapy. Chemotherapy causes children to experience health problems including injuries of the lips and mouth (mucositis), infections, easy bleeding, fatigue, lethargy, hair loss, nausea, vomiting, diarrhea, constipation, decreased appetite, neuropathy, hemorrhagic cystitis, urinary retention, faces that become round and moon face, sleep disorders, and affect the fertility of adult patients (National Cancer Institute, 2010; Hockenberry et al., 2010). Side effects that are often experienced by children to interfere with daily activities, including schools, including the presence of cuts on the lips and mouth (mucositis) (van Vliet, Harmsen, de Bont, \& Tissing, 2010), pain, and fatigue severity in children.

Mucositis is an inflammation and ulceration of the oral mucous membrane (Niscola et al., 2007). The oral mucosa consists of mucous cells that continue to divide rapidly. Disorders in mucous cell division due to chemotherapy would trigger mucositis. Symptoms of mucositis include the onset of pain, ulceration, bleeding, dry mouth, and difficulty speaking (Redding, 2005; Eilers, 2004). If this disorder is not immediately treated, it will lead to further disruption, such as nutritional balance disorders and ultimately result in a decrease in the quality of life in cancer children. Furthermore, mucositis has a variety of negative effects on children (Cancer Care Nova Stovia (CCNS), 2008). The prevalence of mucositis in children with cancer is still being debated because there is currently no consensus on this mucositis incidence rate. However, according to a United Kingdom Children Cancer Study Group and the Pediatric Oncology Nurses Forum or UKCCSG-PONF (2006), the prevalence of mucositis in cancer children is estimated at 30-40\%. Another literature from Stovia's Cancer Care Nova (CCNS) in 2008, said that the mucositis prevalence rate was even greater, which was around $45-80 \%$. In Indonesia, research to 
Sri Hendrawati: The Incidence of Mucositis in Children with Chemotherapy Treatment

identify the incidence of mucositis has not been widely carried out, but the results of the study by Nurhidayah, Sholehati, and Nuraeni (2013) in Dr. RSUP Hasan Sadikin Bandung, showed that most $(67.9 \%)$ of respondents experienced mucositis, both before and after chemotherapy.

Mucositis in children with cancer can be very severe. According to Eilers (2004), mucositis causes various disorders, including physiological disorders and functional disorders. Physiological disorders include the occurrence of lesions, ulceration, excessive inflammation, pain, and infection. Lesions and ulcerations due to mucositis can predispose to bacterial, fungal, and viral infections. This threatens the lives of children because it may become a systemic infection. While, functional disorders due to mucositis including difficult to chew, swallow, and talk. Difficulty swallowing experienced by children is associated with various consequences. Children with dysphagia are more at risk of developing aspiration pneumonia. In addition, dysphagia can also cause a decrease or change in food intake. Consequently, children would experience nutritional problems that require further treatment (Eilers, 2004). According to research conducted by Elting (2006) in Cancer Care Nova Stovia (2008), cancer children who experience mucositis because chemotherapy spends more food through total parenteral nutrition (TPN) and tubes ten times more than patients who do not experience mucositis. The length of the day of care for a cancer child who suffers from mucositis is also seven days longer compared to cancer children who do not experience mucositis. According to Keefe et al. (2007), in the United States patients who experience oral health disorders spend 4,000 US dollars for the cost of treatment.

Referral hospital of child cancer in Indonesia for West Java Province is Dr. RSUP Hasan Sadikin hospital in Bandung city. Observations carried out in the inpatient room of this hospital showed that most children complain of pain due to mucositis which makes it difficult for children to swallow and have difficulty eating and drinking, insomnia, children often wake up due to pain in the oral mucosa and throat, and children cannot speak clearly. The results of the preliminary study showed that most parents reported that their children became fussy, irritable, often complained of pain, unable to swallow food or drink, children's speech ability was reduced, and children had difficulty articulating words clearly.

It is important for nurses to understand the occurrence of mucositis in cancer children who undergo chemotherapy, both before chemotherapy and after chemotherapy, and the factors associated with the occurrence of mucositis in cancer children who undergo chemotherapy, so that nurses can determine the appropriate intervention in accordance with mucositis conditions in cancer child. Nurses as professionals are responsible for providing quality nursing services to prevent and treat mucositis due to chemotherapy. It is necessary to study the incidence of mucositis in cancer children with chemotherapy. This study aimed to identify the occurrence of mucositis in cancer children with chemotherapy at Dr. RSUP Hasan Sadikin Bandung.

\section{Method}

The design of this study was descriptive quantitative. This study aimed to identify the occurrence of mucositis in cancer children with chemotherapy. The population in this study were all children suffering from cancer in the inpatient ward of RSUP Dr. Hasan Sadikin Bandung with an average number of patients 30 people per month. The sample in this study was chosen by consecutive sampling. The sample selection criteria in this study consisted of inclusion criteria and exclusion criteria. The inclusion criteria were 1) pediatric patients with cancer, 2) undergoing treatment or treatment at Dr. RSUP Hasan Sadikin Bandung, and 3) general health conditions are good. Exclusion criteria were children with oral cancer or nasopharyngeal stage 3-4 cancer, and children having difficulty opening their mouths. The period of research was around 3 months starting from July to September 2015 , the number of samples was 60 children with cancer with chemotherapy treatment in the Nursing Room for Children in Kenanga 
Sri Hendrawati: The Incidence of Mucositis in Children with Chemotherapy Treatment

I and II.

Identification of mucositis in children was done using the Oral Assessment Guide (OAG) instrument to assess mucositis in children designed by Eilers, Berger, and Petersen (1988); Dodd (2004); and Eilers (2004). OAG consists of eight assessment parameters, including objective assessment to see the status of mucous membranes, lip, tongue, gingival, and tooth conditions; as well as functional and subjective studies to assess sound; salivary gland function, and swallowing ability. The assessment described in the score 1-3 grades one (1) if normal, the value of two (2) if there is a moderate change, and the value of three (3) if there are severe changes. The method of OAG assessment was done by observation, visual examination, palpation, and auditory. The lowest mucositis value was 8 and the highest value was 24 . Data analysis were done using frequency distribution and percentage. This study has received ethical approval from the Health Research Ethics Committee of Dr. RSUP Hasan Sadikin Bandung with letter number LB.04.01 / A05 / EC / 154 / V / 2015.

\section{Result}

The characteristics of child respondents with cancer in this study are illustrated in the following table.

\section{Table 1 The Characteristics of Respondents}

\begin{tabular}{|c|c|c|c|}
\hline No & Characteristics & Frequency (n) & Percentage (\%) \\
\hline \multirow[t]{5}{*}{1} & Children's ages & & \\
\hline & Toddler & 7 & 11.7 \\
\hline & Preschool ages & 19 & 31.7 \\
\hline & School ages & 31 & 51.7 \\
\hline & Adolescent & 3 & 5.0 \\
\hline \multirow[t]{3}{*}{2} & Gender & & \\
\hline & Male & 39 & 65 \\
\hline & Female & 21 & 35 \\
\hline \multirow[t]{6}{*}{3} & The onset of age diagnosed with cancer & & \\
\hline & $<1$ year & 2 & 3.3 \\
\hline & $1-3$ years & 17 & 28.3 \\
\hline & $4-6$ years & 15 & 25 \\
\hline & $7-9$ years & 14 & 23.3 \\
\hline & $10-12$ years & 12 & 20 \\
\hline \multirow[t]{13}{*}{4} & Types of Cancer & & \\
\hline & ALL-HR & 34 & 56.7 \\
\hline & Neuroblastoma & 2 & 3.3 \\
\hline & HML & 2 & 3.3 \\
\hline & Retinoblastoma & 6 & 10 \\
\hline & AML & 4 & 6.7 \\
\hline & NHML & 4 & 6.7 \\
\hline & Astrocytoma & 1 & 1.7 \\
\hline & Tumor Intra Abdomen & 2 & 3.3 \\
\hline & CML & 1 & 1.7 \\
\hline & William Tumor & 2 & 3.3 \\
\hline & Rhabdomyosarcoma & 1 & 1.7 \\
\hline & Synostosis & 1 & 1.7 \\
\hline
\end{tabular}


Sri Hendrawati: The Incidence of Mucositis in Children with Chemotherapy Treatment

\begin{tabular}{|c|c|c|c|}
\hline 5 & The level of severity & & \\
\hline & Level I & 11 & 18.3 \\
\hline & Level II & 20 & 33.3 \\
\hline & Level III & 8 & 13.3 \\
\hline & Level IV & 21 & 35 \\
\hline \multirow[t]{9}{*}{6} & The cycle of chemotherapy & & \\
\hline & $1-10$ & 42 & 70 \\
\hline & 11-20 & 7 & 11.7 \\
\hline & $21-30$ & 4 & 6.7 \\
\hline & $31-40$ & 1 & 1.7 \\
\hline & $41-50$ & 1 & 1.7 \\
\hline & $51-60$ & 1 & 1.7 \\
\hline & $61-70$ & 3 & 5 \\
\hline & $71-80$ & 1 & 1.7 \\
\hline \multirow[t]{6}{*}{7} & Length of therapy & & \\
\hline & $<1$ year & 39 & 65 \\
\hline & $1-3$ years & 16 & 26.7 \\
\hline & $4-6$ years & 3 & 5 \\
\hline & $7-9$ years & 1 & 1.7 \\
\hline & $10-12$ years & 1 & 1.7 \\
\hline \multirow[t]{3}{*}{8} & Co-morbidities & & \\
\hline & None & 59 & 98.3 \\
\hline & Exist & 1 & 1.7 \\
\hline \multirow[t]{4}{*}{9} & Nutritional status & & \\
\hline & Good nutrition & 42 & 70 \\
\hline & Undernutrition & 14 & 23.3 \\
\hline & Malnutrition & 4 & 6.7 \\
\hline
\end{tabular}

Table 2 Incidences of Mucositis in Children with Chemotherapy $(n=60)$

\begin{tabular}{|c|c|c|}
\hline Incidences & Frequency (n) & Percentage (\%) \\
\hline No Mucositis & 7 & 11.7 \\
\hline Mucositis & 53 & 88.3 \\
\hline
\end{tabular}

Table 1 shows that the majority of children who suffer from cancer are in the developmental stages of school age as many as 31 people $(51.7 \%)$ and the majority of children with cancer of male sex are 39 people $(65 \%)$. When the child was first convicted of cancer, nearly half of the children at that time were in the age range of 1 to 3 years as many as 17 people $(28.3 \%)$. Most of the children as many as 34 people $(56.7 \%)$ were sentenced to suffer ALL.

According to the severity of cancer suffered by the child, almost half of the children had cancer with the severity of degree II as many as 20 people $(33.3 \%)$ and IV as many as 21 people (35.0\%). At the time of the study, most children were undergoing a chemotherapy cycle in the range of cycles 1 to 10 cycles as many as 42 people $(70.0 \%)$. When viewed from the length of time the therapy has been undertaken, most of the children, as many as 39 people $(65.0 \%)$ had just undergone therapy for less than 1 year. Almost all children with cancer undergoing treatment, as many as 59 children (98.3\%) did not have co-morbidities due to cancer. As for $1(1.7 \%)$, children suffer from pulmonary tuberculosis as a cancer-related illness. 
Sri Hendrawati: The Incidence of Mucositis in Children with Chemotherapy Treatment

Viewed from nutritional status, most of the children were as many as 42 people $(70.0 \%)$ with good nutritional status and there was a small portion of as many as 4 people $(6.7 \%)$ with malnutrition status.

The mucositis incidence in children with cancer undergoing treatment in the Kenanga I and II Child Care Room of Dr. RSUP Hasan Sadikin Bandung can be described as follows. Children experienced mucositis as much as $88.3 \%$ (53 people) and did not experience mucositis as much as $11.7 \%$ ( 7 people).

\section{Discussion}

Patients with chemotherapy have a risk of mucositis around $20 \%-40 \%$. Oral mucositis would be characterized by objective signs (erythema, lesions, and edema), subjective changes (pain, sensitivity, and dryness), and changes in function (sound changes, chewing and swallowing) (Potting et al., 2005). Mucositis is caused by cell injury. Cell injury caused by drugs includes side effects of chemotherapy, chemicals, infections, trauma, or tissue irritation due to mechanical objects (such as friction between the mucosa and objects or using improper toothbrushes).

The results of this study indicate that almost all children with chemotherapy treatment experienced mucositis as many as 53 people $(88.3 \%)$, and a small portion of 7 people $(11.7 \%)$ did not experience mucositis. The results of this study inline with Nurhidayah, Sholehati, and Nuraeni (2013) study found that most $(67.9 \%)$ of children with chemotherapy experienced mucositis. According to the United Kingdom Children Cancer Study Group and the Pediatric Oncology Nurses Forum or UKCCSG-PONF (2006), the prevalence of mucositis in cancer children is estimated at 30-40\%. Another literature from Stovia's Cancer Care Nova (CCNS) in 2008, said that the mucositis prevalence rate was even greater, which was around $45-80 \%$.

Mucositis in children with cancer can be very severe. This is related to Back (1999) in Eilers (2004)'s opinion which stated that children have a higher risk of developing mucositis compared to other ages because in children epithelial cells and mucous membranes are more sensitive to toxicity. According to Eilers (2004), mucositis causes various disorders, including physiological disorders and functional disorders. Physiological disorders include the occurrence of lesions, ulceration, excessive inflammation, pain, and infection. Lesions and ulcerations due to mucositis would predispose to bacterial, fungal, and viral infections. This threatens the lives of children because it would become a systemic infection. While functional disorders due to mucositis including difficult to chew, swallow, and talk.

This study shows that $88.3 \%$ of cancer children with chemotherapy suffer from mucositis. According to children's' symptoms, they said that they faced various kinds of disorders, including pain, difficulty sleeping, eating disorders, mood disorders, and disruption of activity. So that all these things have direct implications for the children quality of life. This research in line with the research of Mottalebnejad et al. (2008) which showed that before chemotherapy, almost all respondents did not have mucositis according to the oral mucositis assessment scale (OMAS) score. In addition, Cheng, Chang, and Yuen's (2004) study also stated that most children before chemotherapy did not experience mucositis according to $\mathrm{OAG}$ scores.

Assessing the side effect of chemotherapy in a child is significant including mucositis. The mucositis that occurs may cause a variety of disorders, such as eating difficulties which will eventually cause nutritional disorders. The nutritional disturbance would affect a child's immunity and increase the occurrence of mucositis in children. In addition, mucositis can also cause pain in the oral area which would greatly disrupt the comfort of the child and decrease children's quality of life physically, psychologically, cognitively, and socially (Cheng et al., 2012). Families, especially parents, have a role in caring for children. Research shows that parents as family caregivers have a poor quality of life (Maziyya, Rahayuwati, \& Yamin, 2018). Parents with cancer children have higher stress levels than parents with normal children. Effective coping strategies for parents would help parents avoid excessive stress (Dwirexsi, Lukman, \& Rafiyah, 2018). 
Sri Hendrawati: The Incidence of Mucositis in Children with Chemotherapy Treatment

Nurses as health workers closest to child cancer patients should improve nursing care quality for children with cancer to minimize the occurrence of mucositis due to chemotherapy treatment. Nursing interventions include paying attention to children's oral hygiene, so the oral area is clean and healthy, preventing plaque on the surface of the teeth, keeping the oral mucosa moist, maintaining mucosal integrity, preventing infection, preventing chapped and injured lips, and maintain good mouth function. The oral mucosa damaged by chemotherapy is unavoidable, but the prevention of infection in the mouth would minimize damage to oral tissue.

\section{Conclusion}

The results of this study indicate that all cancer children with chemotherapy treatment experienced mucositis. Nurses as health workers who are most often in contact with children cancer patients should be able to improve nursing care for children with cancer to minimize the occurrence of mucositis due to this chemotherapy treatment. Nursing interventions include paying attention to oral hygiene in children. By paying attention to oral hygiene in children, it would help maintain a clean and healthy oral cavity, preventing the occurrence of plaque on the tooth surface that would prevent dental caries, keeping the oral mucosa moist, maintaining mucosal integrity, preventing infection, preventing chapped and injured lips, and maintaining good mouth function. The oral mucosa damaged by chemotherapy is unavoidable, but the prevention of infection in the mouth would minimize damage to oral tissue. Nurses can develop operational standards for oral care procedures for cancer children who undergo chemotherapy including cleaning the oral mucosa without causing trauma, moisturizing the lips and oral cavity, relieving pain and inflammation, and brushing teeth with a soft toothbrush. This procedure aims to improve the quality of nursing care so that it can ultimately improve the quality of life in cancer children. In addition, nurses should be able to involve the family in the care of cancer children in preventing and detecting the occurrence of mucositis in children so that the occurrence of mucositis can be minimized.

\section{References}

Bartucci, M., Rosanna, D., \& Daniela, M. (2011). Prevention of chemotherapy-induced anemia and thrombocytopenia by constant administration of stem cell factor. Clinical Cancer Research, 17, 6185-6191.

Cancer Care Nova Stovia. (2008). Best practice guidelines for the management of oral complications from cancer therapy. California: Nova Stovia Government. Diperoleh melalui www.cancercare.ns.ca.

Cheng, K.K., Chang, A.M., \& Yuen, M.P. (2004). Prevention of oral mucositis in pediatric patients treated with chemotherapy: A randomized crossover trial comparing two protocols of oral care. European Journal of Cancer, 40(8), 1208-1216.

Cheng, K.K., Lee, V., Li, C.H., Yuen, H.L., \& Epstein, J.B. (2012). Oral mucositis in pediatric and adolescent patients undergoing chemotherapy: The impact of the symptom on quality of life. Support Care Cancer, 20(10), 2335-42. doi: 10.1007/s00520-0111343-1. Epub 2011 Dec 14.

Departemen Kesehatan Republik Indonesia. (2009). Kendalikan kanker. Diperoleh melalui http://www.depkes.go.id/index.php/.

Dodd, M.J. (2004). The pathogenesis and characterization of oral mucositis associated with cancer therapy. Oncology Nursing Forum, 31(4), 5-12.

Dwirexsi, W., Lukman, M., \& Rafiyah, I. (2018). The correlation between coping strategy and stress of parents who have children with autism. Journal of Nursing Care, 1(3), 172-179. https://doi.org/10.24198/jnc. v1i3.17861.

Eilers, J., Berger, A.M., \& Petersen, M.C. (1988). Development, testing and application of oral assessment guide. Oncology Nursing Forum, 15, 325-330. 
Sri Hendrawati: The Incidence of Mucositis in Children with Chemotherapy Treatment

Eilers, J. (2004). Nursing intervention and supportive care for the prevention and treatment of oral mucositis associated with cancer treatment. Oncology Nursing Forum, $31(4), 13-28$.

Fadda, G., Campus, G., \& Lugliè, P.F. (2006). Risk factors for oral mucositis in pediatric oncology patients receiving alkylant chemotherapy. BMC Oral Health, 6(13), 1-8. doi:10.1186/1472-6831-6-13.

Hockenberry, M., \& Wilson, D. (2009). Essential of pediatric nursing. St. Louis: Mosby Year Book.

Hockenberry, M.J., Hooke, M.C., Gregurich, M., McCarthy, K., Sambuco, G., \& Krull, K. (2010). Symptom clusters in children and adolescents receiving cisplatin, doxorubicin, or ifosfamide. Oncology Nursing Forum, $37(1), 16-27$.

Keefe, D.M., Schubert, M.M., Elting, L.S., Sonis, S.T., Epstein, J.B., Raber-Durlacher, J., Migliorati, C.A., et al. (2007). Update clinical practice guidelines for the prevention and treatment of mucositis. American Cancer Society, 109(5), 24-73.

Kementrian Kesehatan RI. (2017). Situasi penyakit kanker. Retrieved from www. depkes.go.id/resources/download/pusdatin/ infodatin/infodatin-kanker.pdf

Mandiacloqlu, A., \& Pamukcu, B. (2004). Anak kanker di negara berkembang. Diperoleh melalui http://www.ncbi.nlm.nih. gov/pub med/15202163.

Maziyya, N., Rahayuwati, L., \& Yamin, A. (2018). Quality of life of family caregiver of the cancer patient: A literature review. Journal of Nursing Care, 1(3), 226-237. https://doi.org/10.24198/jnc.v1i3.18516.

Mottalebnejad, M.,Akram, S., Moghadamina, Moulana, Z., \& Omidi, S. (2008). The effect of topical application of pure honey on radiation-induced mucositis: A randomized control trial. The Journal of Contemporary Dental Practice. Diperoleh melalui http:// www.jaypeejournals.
Murphy, B.A. (2007). Clinical and economi consequences of mucositis induced by chemotherapy and/or radiation therapy. $J$ Support Oncol, 9(4), 13-21.

National Cancer Institute. (2010). Surveillance, epidemiology and end result (SEER). Diperoleh melalui www.seer.cancer. gov/canque/incidence.html.

(2009). A snapshot of pediatric cancer. Diperoleh melalui http:// www.cancer.gov/aboutnci/servingpeople/ cancer-snapshot.

Niscola, P., Romani, C., Cupelli, L., Scaramucci, L., Tendas, A., Dentamaro, T., Amadori, S., \& de Fabritiis, P. (2007). Mucositis in patients with hematologic malignancies: An overview. Haematologica/ The Hematology Journal, 92(02), 222-231.

Nurhidayah, I., Sholehati, S., \& Nuraeni, A. (2013). Skor mukositis pada anak dengan kanker yang sedang menjalani kemoterapi di RSUP Dr. Hasan Sadikin Bandung. Jurnal Keperawatan Soedirman (The Soedirman Journal of Nursing), 8(1), 1-13.

Polit, D.F., \& Beck, C.T. (2008). Nursing research: Generating and assessing evidence for nursing practice, (8th Ed.). Philadelphia: Lippincott Williams \& Wilkins.

Potting C.M.J, Uitterhoeve, R., Reimer, W.S., \& Achterberg, T.V. (2005). The effectiveness of commonly used mouthwashes for the prevention of chemotherapy-induced oral mucositis: A systematic review. European Journal of Cancer Care, 15(1), 431-439.

Price, S.A., \& Wilson, L.M. 2013. Patofisiologi konsep klinis proses-proses penyakit (Edisi VI). Jakarta: EGC.

Redding, S.W. (2005). Transfer of advances in the sciences into dental education: Cancer therapy-related oral mucositis. Journal of Dental Education, 69(8), 919-929.

UKCCSG-PONF. (2006). Mouth care for children and young people with cancer: evidence-based guidelines. Mouth Care 
Sri Hendrawati: The Incidence of Mucositis in Children with Chemotherapy Treatment

Guidelines Report, Version 1, Feb 2006. Diperoleh melalui www.ukccsg.uk.

Umiati, M. (2010). Gambaran kualitas hidup anak usia 1-6 tahun yang menjalani kemoterapi di Rumah Sakit Kanker Darmais, Jakarta Barat. Journal of Cancer, 4(2). van Vliet, M.J., Harmsen, H.J.M., de Bont, E.S.J.M., \& Tissing, W.J.E. (2010). The role of intestinal microbiota in the development and severity of chemotherapy-induced mucositis. PLoS Pathogens, 6(5), 1-7. e1000879.

World Health Organization (WHO). (2009). ENHIS: Incidence of childhood leukemia. 